\title{
A Series on Diseases in the Florida Vegetable Garden: PEPPER 1
}

Ken Pernezny and Tim Momol $^{2}$

Many Floridians delight in maintaining a vegetable garden in their backyard. Others keep several pots of popular vegetables on patios or similar residential sites. Our long growing season and generally mild climate are ideal for the gardening enthusiast. Whats more, the health benefits of moderate gardening activity are well documented, and the supply of wholesome garden-fresh vegetables adds to our quality of life in the Sunshine State.

Sometimes pest problems interfere with our gardening pursuits. Some problems, such as weeds and certain insects, are relatively easy to identify as causing damage. However, another group of maladies, plant diseases, can cause serious damage and are underappreciated and poorly understood by many homeowners.

The majority of plant health problems categorized as plant diseases are caused by microorganisms. As the name implies, these are extremely tiny disease agents that ordinarily require a microscope to be seen. The very minute size of these disease-causing pathogens accounts for the mystery that often surrounds their presence and impact in the garden.
The pathogenic microorganisms that attack garden vegetables, including pepper, can be classified into three major groups: fungi, bacteria, and viruses.

Fungi are seen (100-400x magnification) as threads (hyphae) that absorb food and water from their host (Fig. 1). Many of these fungi reproduce by forming thousands and thousands of spores that are readily blown about by even light winds. These spores can alight on your pepper plants and eventually cause disease. Some fungi have the capacity to survive very long periods of time (10 or more years) in soil in absence of a host. Once peppers are planted in infested soil, these "resting" fungal structures can become viable again and attack plant roots, causing disease.

Bacteria are even smaller than fungi (you need a 1000x magnification with a special light microscope to see them) (Fig. 2). They consist of only one cell and do not form the airborne spores that fungi do. Rather than being blown by the wind, bacteria are usually spread by splashing water, as in rainstorms or overhead sprinkler irrigation. They can also be spread by gardeners who touch diseased plants and

1. This document is Fact Sheet PP-201, one of a series of the Plant Pathology Department, Florida Cooperative Extension Services, Institute of Food and Agricultural Sciences, University of Florida. Published July 2004. Please visit the EDIS Website at http://edis.ifas.ufl.edu/

2. Ken Pernezny, Professor of Plant Pathology, Univ.Fla., IFAS, Everglades Research and Education Center, Belle Glade; and Tim Momol, Associate Professor of Plant Pathology, Univ.Fla., IFAS, North Florida Research and Education Center, Quincy.

The Institute of Food and Agricultural Sciences (IFAS) is an Equal Employment Opportunity - Affirmative Action Employer authorized to provide research, educational information and other services only to individuals and institutions that function without regard to race, creed, color, religion, age, disability, sex, sexual orientation, marital status, national origin, political opinions or affiliations. For information on obtaining other extension publications, contact your county Cooperative Extension Service office. Florida Cooperative Extension Service / Institute of Food and Agricultural Sciences / University of Florida / Larry R. Arrington, Interim Dean 


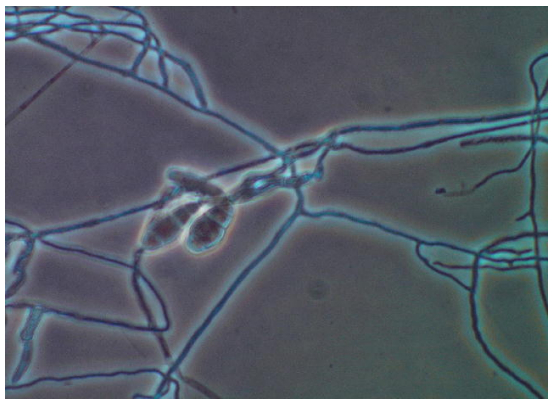

Figure 1. Microscopic threads (hyphae) and spores of a typical plant-pathogenic fungus.

healthy plants in succession without thoroughly washing their hands in-between.

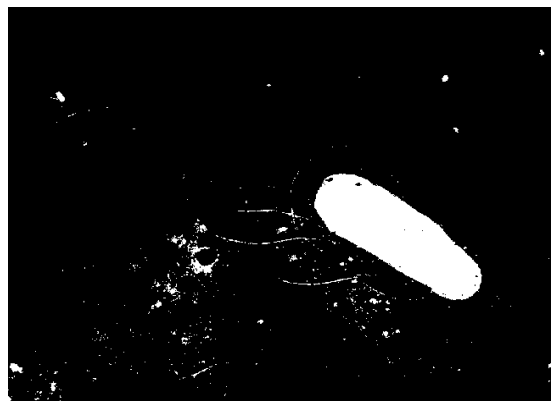

Figure 2. A bacterial cell Credits: Photo courtesy of J. B. Jones

Viruses are most strange indeed. (Fig. 3). They are not "organisms" in the sense of the fungi and bacteria. They are very large molecular structures consisting of a nucleic acid (DNA or RNA) wrapped in a protective coating of protein. Once inside pepper cells, they take over the host cellular machinery and use it to produce more viruses. Most of the important pepper viruses are transmitted to garden plants by insects such as aphids, whiteflies, or thrips.

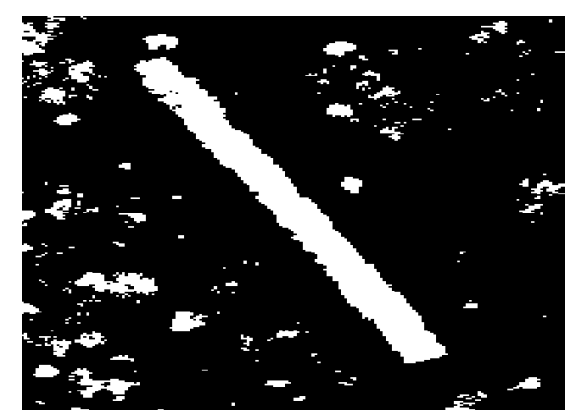

Figure 3. Typical rod shaped virus as seen through a powerful electron microscope. Credits: Photo courtesy of Scott Adkins, USDA

The following diseases are a few of the ones, in our experience, that are most likely to appear on your garden peppers. This is not by any means an exhaustive list of pepper diseases, but the ones we feel occur most often in Florida home gardens. If you have a problem that you think might be a disease not covered in this publication, search the EDIS database or that of the Department of Plant Pathology web site of IFAS University of Florida for information on additional pepper diseases. Legal uses and effectiveness of plant disease control chemicals change with time. You are strongly advised to consult your local UF IFAS Cooperative Extension office for current disease management recommendations.

\section{Bacterial spot}

Bacterial spot is one of the most common diseases of pepper every year in Florida, occuring in both commercial fields and home gardens. It is caused by the bacterium Xanthomonas campestris pv. vesicatoria.

All above-ground parts of the pepper plant can develop symptoms. On leaves, the first symptoms are the appearance of spots on the lower leaf surface that look watersoaked. They are not actually wet but give the distinct impression of being filled with water. These become brown to black in a few days and greasy looking (Fig. 4). The majority of leaf spots are surrounded by a yellow halo. Individual lesions (spots) may run together to form extensive blighted areas. In drier, cooler conditions, lesions may appear more tan to light brown without marked watersoaking (Fig. 5). Infected leaves may fall off plants prematurely, even when only a few spots form.

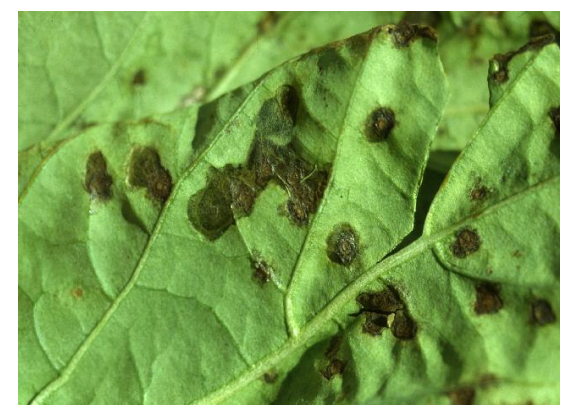

Figure 4. Bacterial spot on pepper leaf under moist conditions.

Symptoms on pepper fruit are very distinctive. These fruit lesions begin as small, raised pimples that are a bit lighter in color than the normal dark green 


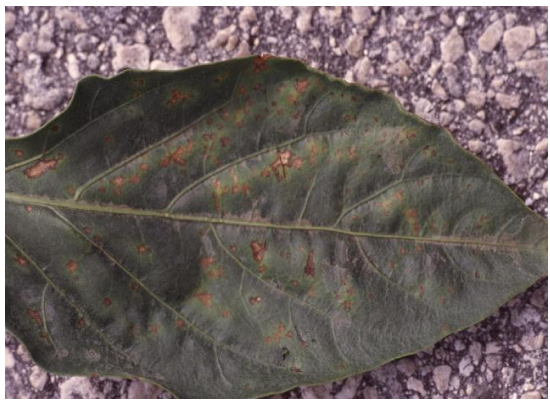

Figure 5. Bacterial spot on pepper leaf under dry conditions.

fruit color. They enlarge over time and become scabby looking (Fig. 6).

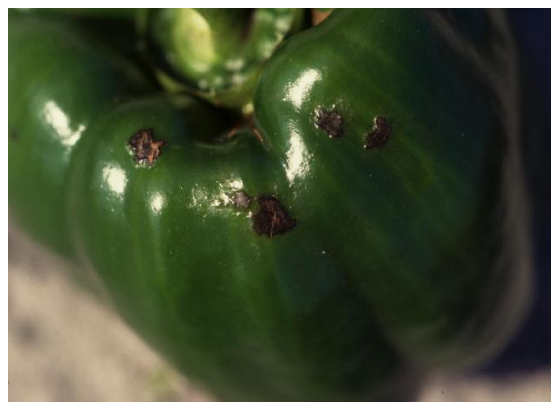

Figure 6. Bacterial spot on pepper fruit.

Control of bacterial spot is difficult once introduced into the garden. Therefore, you are advised to do all you can to prevent introduction of the pathogen when the garden is established. If you start your plants from seed, purchase the seed from an established, reputable seed company. This will increase the likelihood that your seed is free of spot bacteria. When purchasing transplants from a retail nursery, inspect the plants carefully for symptoms of bacterial spot. Avoid purchase of diseased plants. Try to avoid overhead, sprinkle irrigation as much as possible. Bacterial spot is a warm, rainy weather disease; problems with this disease can be minimized simply by growing peppers in the cooler, drier months.

Use of resistant varieties of pepper is an important strategy for control of bacterial spot. There are several types of the bacterial spot pathogen in Florida. These distinct types are known as races. Although at least 10 races are known, three races (race 1, 2, and 3) have often been the dominant ones in our state. Several pepper varieties with resistance to races 1 through 3 are available for sale. Ask your seed supplier or transplant vendor if they have varieties with resistance to these races. Of course, if races other than 1,2 , or 3 attack, these varieties will not withstand the bacterial spot disease.

Copper-containing fungicide (bactericide) sprays that can be purchased at garden centers may provide some control of bacterial spot.

\section{Anthracnose}

Anthracnose is a fungus disease cause by Colletotrichum spp. It is a disease of both sweet bell, banana, and hot pepper fruit. Lesions (spots) can develop on fruit of any age, but symptoms are much more common on ripening fruit (i.e., those changing color from green to red, yellow, or a number of other mature colors).

Fruit spots are more or less circular and can enlarge rapidly, reaching diameters of 2 inches or more (Fig. 7). There may be concentric rings in the middle of these large spots, which are a direct result of growth of the fungus. Sometimes these rings are orange or "salmon-colored", as a result of the accumulation of large numbers of fungus spores.

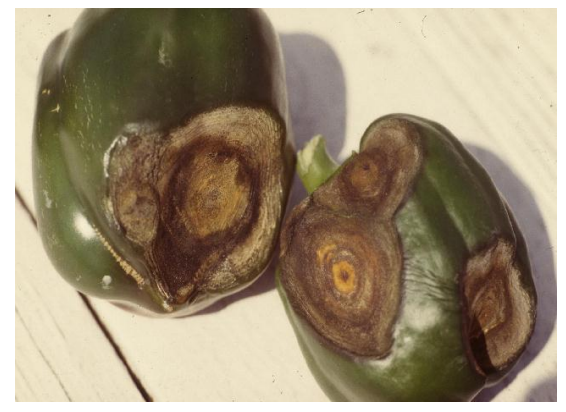

Figure 7. Anthracnose symptoms on green pepper fruit.

Anthracnose is favored by prolonged periods of rain and high relative humidity. It can occur throughout the range of temperatures that we encounter when growing peppers in Florida, but is considered a disease of "moderate" temperatures (daytime highs in the 70s and 80s).

This disease can be especially difficult to control if it gains entry to a garden. If it is a continuing problem on ripe (colored) fruit, the gardener may have to consider harvesting more fruit when mature but still green. Several fungicides will aid in control of anthracnose, but even use of these chemicals does not help very much if the weather is favorable for the 
disease. If chemical control is needed, the spray program must be initiated at the first sign of disease on the youngest fruit.

\section{Common virus diseases}

A number of virus diseases affects pepper in Florida. These diseases have been noted occasionally in garden peppers. Most of the viruses that infect pepper are transmitted to healthy plants by aphids, tiny insects with piercing, sucking mouthparts that feed on plant sap. When aphids feed on virus-infected plants, they may pick up virus on their mouthparts and infect healthy plants during subsequent feedings.

Symptoms of most of these viruses are quite similar, and laboratory tests are needed to identify exactly which virus is involved. Usually, it is not necessary that the home gardener knows which virus is the culprit; it is sufficient to know that the peppers have a virus disease.

Virus-infected plants have mosaic patterns consisting of bands of light green or yellow alternating with dark green. Sometimes the leaves are crinkled or otherwise distorted (Fig. 8). Very often, plant growth is stunted. Mottled patterns and distortion may also be evident on fruit, with an uneven ripening of the fruit flesh (Fig.8). It is not uncommon for virus symptoms to be subtle; sometimes it takes a diligent and observant gardener to know that something is wrong.

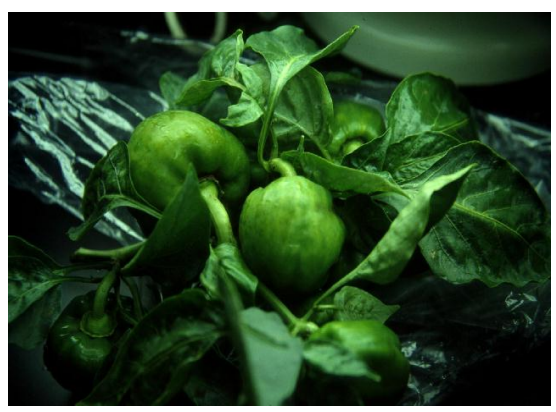

Figure 8. Aphid transmitted virus symptoms on leaves and fruit of pepper.

A notable exception to the transmission of pepper viruses by aphids is tobacco mosaic virus (often abbreviated TMV). This is one of the oldest known virus affecting pepper. It is mechanically transmitted. This means that it is moved from plant to plant on the hands and clothing of gardeners and on contaminated garden tools. It may very well be introduced into gardens on infected transplants. Some tobacco products can be sources of TMV.

Virus disease management entails use of a number of tactics. Destroy solanaceous weeds (weeds in the same family as pepper, tomato, potato, etc.) such as nightshade and ground cherry. Remove infected plants at first sign of disease. Plant earlier in the fall in southern Florida to avoid the aphid flights traditionally associated with the cooler winter months (but remember, such plantings are more likely to have problems with bacterial spot). Unfortunately, insecticidal sprays to control aphids have had poor success in controlling viral diseases.

With respect to TMV, avoid tobacco products when working around the garden. Use disease-free transplants. Washing hands and tools in milk, believe it or not, will do an excellent job of inactivating TMV and sharply reduce transmission of this disease.

\section{Tomato spotted wilt virus}

Tomato spotted wilt virus (TSWV) is such a unique virus that we chose to present it separately from the viruses in the previous section. It is spread primarily by the insect thrips and not by aphids. The symptoms are often quite striking and consist of stunted plants (Fig. 9), mosaic and ring patterns (Fig. 10) on leaves and fruit, and general browning of all above-ground plant parts. This disease is found mostly north of Orlando, presumably because the thrips species that are best adapted to spread TSWV are more abundant in northern parts of the state. However, it may occur in south Florida too.

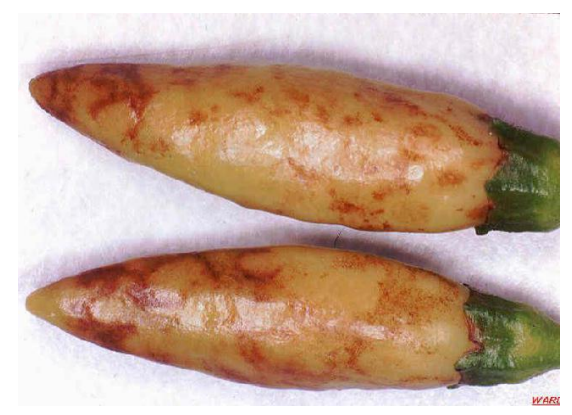

Figure 9. TSWV on tobasco pepper. Credits: Photo courtesy of Hank Dankers 


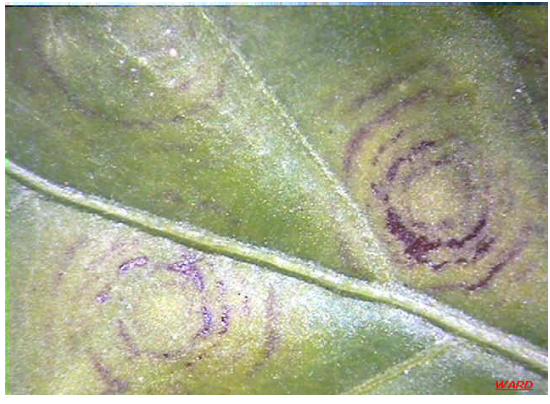

Figure 10. Ring pattern on leaf due to TSWV. Credits: Photo courtesy of Hank Dankers

Maintain good weed control to help reduce TSWV. Control of thrips with insecticides might help, but in controlled experiments, insecticides have not been all that successful. In order to keep the existing beneficial predator (i.e. Minute pirate bugs Orius sp.) population, use thrips-specific insecticides when needed.

\section{Cercospora leaf spot (frogeye leaf spot)}

Cercospora leaf spot, also known by the rather peculiar term frogeye leaf spot, is encountered on a regular basis in gardens in northern Florida. The fungus survives the winter in northern Florida and is most troublesome in warm, wet weather. It is uncommon south of Orlando. Symptoms occur in leaves, stems, and the stalks of both leaves and fruit. However, no symptoms of this disease ever occur on the pepper fruit themselves. Leaf lesions are quite distinctive and allow for quick and relatively easy field diagnosis. Leaf spots are circular to somewhat oval with a light tan center and a distinctive dark red border (Fig. 11). Under moist conditions, the causal fungus, Cercospora capsici, may be observed growing in the tan area of the spots, especially if a $10 \mathrm{x}$ hand lens is available.

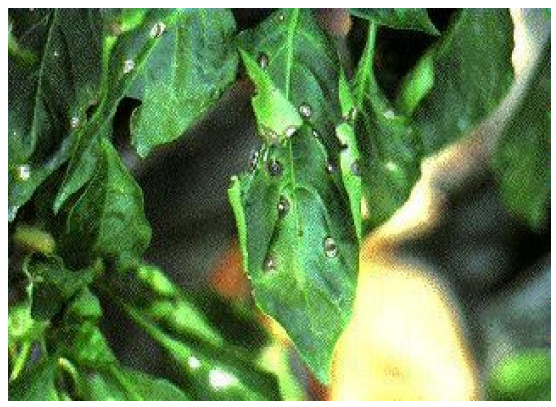

Figure 11. Cercospora leaf spot (frogeye leaf spot). Credits: Photo courtesy of T. Kucharek and K. Pernezny)
Promptly destroy infected plants in the garden when your season ends in order to minimize carry-over to the next planting season. Fungicide sprays may be necessary if Cercospora leaf spot is a recurring problem. 